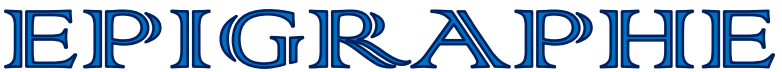 \\ (Jurnal Teologi dan Pelaynnan Kristiani)
}

Volume 1, Nomor 1, November 2017 (119-138)

ISSN: 2579-9932 (online), 2614 - 7203 (print)

http://www.stttorsina.ac.id/jurnal/index.php/epigraphe

\section{Pengaruh Pengajaran dan Persekutuan Terhadap Tingkat Pertumbuhan Rohani Anak dan Remaja}

\author{
Helen Farida Latif \\ Sekolah Tinggi Teologi Pelita Bangsa Jakarta \\ helen.farida@sttpb.ac.id
}

Article History

Received:

November 2017

(printed)

Published:

November 2017

(printed)

Keywords:

fellowship; piritual growth; teaching
Kata kunci: digitilisasi; era digital; gereja; karunia; karunia menulis; pelayanan

\begin{abstract}
Evangelism to the lost souls is very important for the church to do, and no less important that the church should do, that is, to increase the spiritual growth of the church. In order for the spirituality of the church, including children and youth to experience growth until full maturity according to the will of God is necessary for continuous coaching through teaching and fellowship. In this research, the authors identify that the teaching and the fellowship have a very significant influence on the spiritual growth of children and youth, especially in the Gereja Sungai Yordan Keluarga Allah Kutabumi, Tangerang. This research is to determine the influencing of the teaching and the fellowship to the spiritual growth of children and adolescents. The research was conducted by analyzing data on the presence of children and adolescents in the Bible teaching classes and the fellowship and their spiritual growth based scores on Ephesians 4:13-15 and Acts 2:41-47 using scale interval.
\end{abstract}

\begin{abstract}
Abstrak
Pekabaran Injil kepada jiwa-jiwa yang terhilang sangat penting untuk dilakukan gereja, dan yang tidak kalah penting yang harus juga dilakukan oleh gereja, yaitu meningkatkan pertumbuhan kerohanian jemaat. Agar kerohanian jemaat, termasuk anak-anak dan remaja dapat mengalami pertumbuhan sampai tingkat kedewasaan penuh sesuai kehendak Tuhan perlu dilakukan pembinaan secara terus-menerus melalui pengajaran dan persekutuan. Dalam penelitian ini, penulis mengidentifikasi bahwa pengajaran dan persekutuan memiliki pengaruh yang sangat signifikan bagi pertumbuhan kerohanian anak-anak dan remaja, khususnya di Gereja Sungai Yordan Keluarga Allah Kutabumi, Tangerang. Penelitian ini adalah untuk mengetahui ada tidaknya dan sejauh mana pengajaran dan persekutuan dalam mempengaruhi pertumbuhan rohani anak-anak dan remaja. Penelitian ini dilakukan dengan menganalisa data mengenai kehadiran anak-anak dan remaja di kelas pengajaran Alkitab dan komsel serta nilai-nilai (skor) pertumbuhan rohani mereka yang berdasarkan kriteria pada Efesus 4:13-15 dan Kisah Para Rasul 2:41-47 dengan menggunakan skala interval.
\end{abstract}




\section{Pendahuluan}

Peranan gereja selain bagi pekabaran Injil kepada orang-orang yang belum diselamatkan, juga sangat penting bagi pembangunan tubuh Kristus di dunia ini, terutama dalam membangun kehidupan rohani jemaatnya agar bertumbuh menjadi jemaat yang dewasa rohaninya, termasuk kepada anak-anak dan remajanya sebagai generasi penerus kerajaan Allah di bumi ini. Hal ini sesuai dengan yang dikatakan firman Tuhan dalam Amsal 22:6, bahwaTuhan memandang sangat penting untuk mengajar dan mendidik anak-anak dan remaja dalam kebenaran firman Tuhan agar mereka tetap setia kepada Tuhan sampai masa tuanya.

Gereja sebagai perpanjangan tangan Tuhan dalam memperlebar kerajaan-Nya di muka bumi ini perlu memberikan fasilitas yang baik bagi pengajaran firman Tuhan dan menyediakan persekutuan yang sehat bagi anak-anak dan remajanya untuk bertumbuh dalam pengenalan yang benar kepada Allah.

Anak-anak dan remaja yang dalam masa pertumbuhannya memiliki masalahnya sendiri dalam beradaptasi dengan berbagai perubahan dalam dirinya yang berkaitan dengan perubahan-perubahan yang terjadi pada diri mereka, baik perubahan secara fisik dan psikis berkaitan dengan pertambahan usia, maupun perubahan perkembangan kepribadian, sosial maupun lingkungan, mungkin saja dapat menimbulkan problema tambahan tertentu bagi diri mereka. Apabila hal ini tidak disertai upaya pembinaan dan bimbingan secara tepat dari pihak-pihak yang berkompeten, sangat memungkinkan akan muncul hal-hal negatif dan bahkan dapat menjurus pada berbagai tindakan kenakalan remaja dan kriminal.

Dalam mencermati masalah dan problema yang mungkin ditimbulkan serta guna mencegah dampak-dampak negatif dari problema yang mungkin muncul dari perubahan hidup mereka, sangatlah bijaksana bila orang tua dan gereja secara bersama melakukan tindakan-tindakan yang cerdik bagi anak-anak dan remaja agar mereka tidak terjebak ke dalam dampak-dampak negatif akibat berbagai perubahan itu.

"Pertumbuhan gereja adalah kenaikan yang seimbang dalam kuantitas, kualitas dan kompleksitas organisasi sebuah gereja" (Jenson-Stevens, 2004 : 30). Dapat diartikan, bahwa suatu gereja baru dapat dikatakan mengalami pertumbuhan bila telah terjadi pertambahan jumlah anggotanya dan juga diikuti pertambahan kualitas/pertumbuhan rohani jemaatnya. Gereja bukan hanya dapat mempertahankan eksistensinya sebagai sebuah organisasi di dunia ini, tetapi terlebih penting, gereja yang 
adalah sebuah organisme akan terus mengalami pertumbuhan baik dari segi kualitas maupun kuantitas selama dunia ini masih ada.

\section{Pengajaran}

Marthin Luther mengatakan pengajaran/pendidikan agama adalah melibatkan semua warga jemaat, khususnya yang muda, dalam rangka belajar teratur dan tertib agar semakin sadar akan dosa mereka serta bergembira dalam firman Yesus Kristus yang memerdekakan mereka disamping memperlengkapi dengan sumber iman sehingga mereka mampu melayani sesama termasuk masyarakat dan negara serta mengambil bagian secara bertanggung jawab dalam persekutuan Kristen, yaitu gereja. Sementara itu John Calvin mengatakan bahwa pendidikan agama adalah pendidikan yang bertujuan mendidik semua putra-putri gereja untuk mengabdi kepada Allah Bapa dan Yesus Kristus (Boehlke, 2000 : 342, 414).

Pengertian pengajaran/pendidikan agama (Kristen) menurut Dr. E.G. Homrighausen memiliki tujuan, dimana dengan menerima pendidikan itu, segala pelajar, muda dan tua, memasuki persekutuan iman yang hidup dengan Tuhan sendiri, dan oleh dan dalam Dia mereka terhisap pula pada persekutuan jemaat-Nya yang mengakui dan mempermuliakan nama-Nya di segala waktu dan tempat" (Homrighausen dan Enklaar, $1982: 26$ ).

Hal ini sangat berkaitan erat dengan kehendak Tuhan Yesus sendiri seperti dalam Matius 28:19-20 yang memberikan perintah agar pengajaran harus diterapkan dalam kehidupan bergereja dan dalam Kisah Para Rasul 2:42 tentang umat Tuhan yang terus bertekun dalam pengajaran rasul-rasul dan dalam persekutuan, juga dalam Efesus 4:1112 dikatakan-Nya bahwa Ia telah memberikan baik rasul-rasul maupun nabi-nabi, pemberita-pemberita Injil maupun gembala-gembala dan pengajar-pengajar, untuk memperlengkapi orang-orang kudus bagi pekerjaan pelayanan, bagi pembangunan tubuh-Nya.

Pernyataan-pernyataan ini sangat tepat sehingga memberikan satu dorongan akan pentingnya pengajaran firman Tuhan bagi hidup orang percaya untuk mengalami kehidupan yang diubahkan. Demikian pula bagi anak-anak dan para remaja, mereka akan menjadi generasi-generasi muda yang kuat dan cinta Tuhan, yang berkomitmen, yang tidak tergoyahkan oleh goncangan apapun, yang memiliki karakter Kristus dalam hidupnya, dan yang membawa dampak yang baik bagi lingkungan dimana mereka berada. 
W. Stanley Heath mengatakan bahwa kalau kita ingin menyaksikan pertumbuhan gereja yang stabil, maka kita harus memperioritaskan anak kecil dalam pelayanan kita. Banyak anak yang diinjili sewaktu kecil akan bersedia menaruh masa depannya di tangan Tuhan untuk menjadi seorang gembala sidang, penginjil, atau sesepuh awam (Lenga, 2003 : 63). Karena itu sangatlah penting untuk memberikan pengajaran dalam kebenaran firman Allah kepada anak-anak dan remaja secara intensif karena selain agar mereka mengalami pertumbuhan rohani, juga karena mereka adalah calon-calon pemimpin gereja di masa mendatang dan sebagai generasi penerus pembangunan tubuh Kristus di muka bumi ini. Sekalipun anak-anak dan remaja memiliki daya tangkap yang berbeda-beda, tetapi sungguh dapat dipercaya bahwa firman Allah yang ditaburkan melalui pengajaran maupun persekutuan itu tidak akan kembali kepada Allah dengan sia-sia (Yesaya 55:10-11).

\section{Persekutuan}

Bertekun dalam pengajaran dan persekutuan merupakan kebiasaan jemaat mulamula yang membuat mereka mengalami pertumbuhan dalam kualitas dan kuantitas (Kisah Para Rasul 2:42). Wagner (2000) memberikan tanggapan mengenai kelompok sel: "Sebagai contoh, mengapa kampanye-kampanye penginjilan sekota yang terusmenerus begitu populer dari dekade ke dekade, menemukan bahwa begitu sedikit yang bertobat yang berada di gereja lokal setelah satu tahun berlalu? Yang terjadi adalah orang-orang yang mengambil keputusan untuk pertama kalinya untuk terima Yesus pada kampanye tersebut, jumlah yang bertahan di gereja-gereja lokal hanya sekitar 3 sampai $16 \%$. Tidak seorang pun yang saya ketahui, termasuk para penginjil itu sendiri yang gembira dengan angka ini. Banyak gereja yang memiliki pelayanan penginjilan yang kuat dan banyak melihat yang baru bertobat yang datang ke gereja mereka, ternyata juga memiliki pintu belakang yang terbuka lebar-lebar. Kebanyakan gerejgereja yang telah berhasil mempertahankan persentase terbesar dari penuaian tersebut adalah gereja-gereja yang telah berhasil mengembangkan infrastruktur mereka.

Ada berbagai cara dalam berurusan dengan infrastruktur, tetapi mayoritas gereja yang telah berhasil hari ini dan yang telah menghancurkan penghalang pertumbuhan adalah gereja-gereja yang menekankan pada kelompok sel" (Comiskey, 1998 : vii). Cho mengatakan bahwa dia sangat menekankan kepada pentingnya arti mempertahankan kelompok sel sebagai sarana dalam lingkungan gereja untuk melebarkan sayap keluar 
dan salah satu masalah yang ditemui sekelompok orang-orang yang mengadakan himpunan pertemuan secara tetap dan teratur ialah bahwa mereka menjadi tertanam kaku di dalam lingkungan kelompok mereka sendiri (1985 : 69). Pdt. Obaja Tanto juga mengatakan bahwa pemuridan dalam kelompok sel menjadi urat nadi bagi prinsip dua belas. Pemuridan yang dilakukan dalam kelompok sel akan efektif jika dilakukan sama seperti yang Tuhan Yesus sendiri lakukan ketika memuridkan kedua belas murid-Nya $(2000,103)$.

\section{Pertumbuhan Rohani}

Wagner yang digelari sebagai Profesor Pertumbuhan Gereja di tingkat pascasarjana memandang sangat berarti pertumbuhan gereja dilihat dari sisi kualitas atau pertumbuhan rohani gereja (2001 : 13). Dia juga mengatakan pertumbuhan gereja adalah meliputi segala sesuatu yang ada sangkut pautnya dalam usaha membawa orangorang yang tidak mempunyai hubungan pribadi dengan Yesus Kristus kepada persekutuan dengan-Nya. Dan membawa mereka menjadi anggota gereja yang bertanggung jawab (Lenga, 2003). Jadi, pertumbuhan gereja bukan hanya menjadikan orang yang tidak percaya menjadi percaya kepada Tuhan Yesus Kristus (pertumbuhan secara kuantitas), tetapi juga menjadikan mereka menjadi orang-orang yang dewasa rohani dan bertanggung jawab (pertumbuhan secara kualitas).

Warren menjelaskan bahwa pertumbuhan gereja merupakan akibat wajar dari gereja yang sehat. Gereja yang sehat hanya dapat terjadi bila khotbah kita alkitabiah dan misi kita seimbang. (2004). Artinya, sebuah gereja jika pengajarannya benar dan misinya seimbang akan mengalami pertumbuhan secara kuantitas dan kualitas. Himawan Djaya juga mengatakan ada 3 ciri orang yang telah mengalami kedewasaan dalam Kristus: takut akan Tuhan, memanfaatkan potensi diri melalui pikiran, perkataan dan perbuatan, dan memiliki pola tingkah laku yang komprehensif (2003, 21-32).

Alkitab memberikan 8 hal berkaitan dengan kedewasaan rohani dan tingkat pertumbuhan yang sesuai dengan kepenuhan Kristus dalam Efesus 4:13-15 dan Kisah Para Rasul 2:41-47, yaitu: Mencapai kesatuan iman;Memiliki pengetahuan yang benar tentang Kristus; Teguh berpegang kepada kebenaran; Bertumbuh dalam kasih kepada Allah dan sesama; Meningkat hubungan dengan Allah; Terjadi kesatuan antar sesama anggota jemaat; Hidup yang memberkati sesama; Berani memikul tanggung jawab dalam pelayanan. 


\section{Metodologi}

Populasi dalam penelitian ini adalah jemaat yang ada di departemen Anak dan departemen Remaja sebanyak 62 orang, yang terdiri dari anak-anak berusia 1-14 tahun sebanyak 27 orang dan remaja berusia 15-22 tahun sebanyak 35 orang. Sampel yang diambil adalah keseluruhan anak-anak yang sudah berumur 11-14 tahun sebanyak 8 orang dan remaja berumur 15-18 tahun sebanyak 21 orang, dan total sampel 29 orang.

\section{Teknik Analisis}

\section{Hipotesis Penelitian}

Hipotesis I: Semakin tinggi tingkat pengajaran, maka semakin tinggi tingkat pertumbuhan rohani anak-anak dan remaja.

Hipotesis II: Semakin tinggi tingkat persekutuan, maka semakin tinggi tingkat pertumbuhan rohani anak-anak dan remaja.

Hipotesis III: Semakin tinggi tingkat pengajaran dan persekutuan, maka semakin tinggi tingkat pertumbuhan rohani anak-anak dan remaja.

\section{Analisis Data}

Analisis data yang sudah dikumpulkan dibuat dalam 2 tahap, yaitu:

Pertama, menggambarkan keadaan masing-masing konsep dengan menggunakan teknik analisis statistik deskriptif.

Kedua, hipotesis diuji dengan menggunakan statistik uji hipotesis (Dayan, 1983: 367), yaitu: Korelasi Berganda dan Regresi Berganda

\section{Hasil dan Pembahasan}

\section{Analisis}

\section{Deskripsi Masing-masing Variabel Penelitian}

Berdasarkan perhitungan yang dilakukan dengan program Statistical Product Service Solution (SPSS) 17 for Windows, maka data-data tentang pengajaran, persekutuan, dan pertumbuhan rohani dapat digambarkan seperti yang nampak pada dua tabel di bawah ini:

Deskripsi Statistik variabel Pengajaran, Persekutuan, dan Pertumbuhan Rohani

\begin{tabular}{|lllccc|}
\hline Vb. & Mean & SD & \multicolumn{2}{c|}{ Nilai } & Range \\
\hline & & & Min & Maks & \\
\hline X1 & 29,828 & 10,597 & 14,00 & 43,00 & 29,00 \\
\hline X2 & 32,138 & 11,507 & 12,00 & 44,00 & 32,00 \\
\hline Y & 117,414 & 52,824 & 45,00 & 185,00 & 140,00 \\
\hline
\end{tabular}


Tabel Frekuensi Pengajaran, Persekutuan, dan Pertumbuhan Rohani Anak-anak

\begin{tabular}{|cccccccccc|}
\hline Vb. Mean & St Er of Mn & Median & SD & Variance & Skewness & St Er of Sk & Kurtosis & St Er of Kt \\
\hline X1 & 29,828 & 1,968 & 30,000 & 10,597 & 112,291 & $-0,350$ & 0,434 & $-1,410$ & 0,845 \\
\hline X2 & 32,138 & 2,137 & 38,000 & 11,507 & 132,409 & $-0,728$ & 0,434 & $-1,047$ & 0,845 \\
\hline Y & 117,414 & 9,809 & 120,000 & 52,824 & 2790,394 & $-0,065$ & 0,434 & $-1,557$ & 0,845 \\
\hline
\end{tabular}

Keterangan: $\mathrm{X} 1=$ Pengajaran dinyatakan dalam minggu

$\mathrm{X} 2=$ Persekutuan dinyatakan dalam minggu

$\mathrm{Y}=$ Pertumbuhan rohani dinyatakan dalam skor

Berdasarkan tabel di atas, maka variabel pengajaran, variabel persekutuan, dan variabel pertumbuhan rohani anak-anak dan remaja dapat diuraikan dan dijelaskan secara lebih terperinci.

\section{Pengajaran}

Mean (rata-rata) pengajaran yang dihadiri anak-anak dan remaja adalah 29,828 minggu dengan standard error of mean 1,968 minggu (penggunaan standard error of mean untuk memperkirakan besar rata-rata populasi yang diperkirakan dari sampel), maka rata-rata populasi pengajaran pada tingkat kepercayaan $95 \%$ menjadi:

Rata-rata \pm (t tabel x standard error of mean)

$=>29,828 \pm(2 \times 1,968$ minggu $)=25,892$ sampai 33,764 minggu.

Rumus di atas dijelaskan oleh Santoso (2009 : 165) sebagai berikut:

Karena jumlah sampel 29 adalah di bawah 30, maka digunakan angka t tabel. Jika $\mathrm{N}>30$, digunakan angka $\mathrm{z}$ tabel. Angka $\mathrm{t}$ tabel digunakan untuk tingkat kepercayaan $95 \%$ dengan $\mathrm{df}=\mathrm{N}-1$.

Untuk banyak kasus praktis, angka 2 dapat digunakan untuk t tabel atau z tabel. (Angka t tabel dengan df $=29-1=28$ dengan tingkat kepercayaan 95\% adalah 2,048, yang dapat dibulatkan menjadi 2).

Dengan rata-rata kehadiran pengajaran sampel (anak-anak dan remaja) 29,828 minggu, diperkirakan rata-rata kehadiran pengajaran populasi (semua jemaat yang ada di departemen Anak dan Remaja adalah antara 25,892 sampai 33,764 minggu. Tingkat kepercayaan 95\% menunjukkan bahwa ada kemungkinan kesalahan sebesar 5\% dalam generalisasi data. 
Angka median 30 minggu menunjukkan bahwa 50\% anak-anak dan remaja menghadiri pengajaran 30 minggu ke atas, dan 50\% menghadiri pengajaran 30 minggu ke bawah.

Standar deviasi adalah 10,597 minggu dan varians yang merupakan kelipatan standar deviasi (10,597) adalah 112,291 minggu. Angka ini menunjukkan data bervariasi.

Ukuran skewness adalah $-0,350$. Untuk penilaian, nilai tersebut diubah ke angka rasio dengan rumus: rasio_skewness = Skewness / standard error of skewness dan dengan pedoman: jika rasio skewness berada di antara -2 sampai dengan +2 , maka distribusi data adalah normal. Jadi rasio skewness pengajaran anak-anak dan remaja = $0,350 / 0,434=-0,806$. Karena $-0,806$ terletak pada daerah antara -2 dan +2 , maka bisa dikatakan distribusi sampel data pengajaran adalah normal.

Ukuran kurtosis adalah $-1,410$. Untuk penilaian, nilai tersebut diubah ke angka rasio dengan rumus: rasio_kurtosis = kurtosis / standard error of kurtosis dan dengan pedoman: jika rasio kurtosis berada di antara -2 sampai dengan +2 , maka distribusi data adalah normal. Jadi rasio kurtosis pengajaran anak-anak dan remaja $=-1,410 / 0,845=-$ 1,669. Karena $-1,669$ terletak pada daerah antara -2 dan +2 , maka bisa dikatakan distribusi sampel data pengajaran adalah normal.

Data kehadiran minimum pengajaran anak-anak dan remaja adalah 14 minggu, sedangkan data kehadiran maksimum pengajaran adalah 43 minggu. Range adalah 29 minggu, menunjukkan data tersebut bervariasi.

Percentiles atau angka persentil: 10\% responden menghadiri pengajaran di bawah 14 minggu, atau rata-rata kehadiran pengajaran 90\% responden $(100 \%-10 \%)$ di atas 14 minggu. 25\% responden menghadiri pengajaran di bawah 17,50 minggu. Ratarata kehadiran pengajaran 50\% responden di bawah 30 minggu, atau rata-rata kehadiran pengajaran 50\% responden di atas 30 minggu. $75 \%$ responden menghadiri pengajaran di bawah 40 minggu. Rata-rata kehadiran pengajaran 90\% responden adalah di bawah 42 minggu.

Pada tabel frekuensi tentang tingkat kehadiran pengajaran anak-anak dan remaja, dapat dijelaskan sebagai berikut:

Pada baris pertama, responden yang menghadiri kelas pengajaran 14 minggu sebanyak (frekuensi) 4 orang atau (4/29 x 100\%) 13,8\% dari 29 sampel yang ada. Berikutnya baris kedua, responden yang menghadiri kelas pengajaran 15 minggu 
sebanyak 1 orang $(1 / 29 \times 100 \%)$ atau hanya 3,4\% dari total sampel. Dengan demikian, kedua frekuensi tersebut mempunyai kumulatif persen sebesar 13,8\% + 3,4\% atau 17,2\%. Demikian seterusnya hingga sampai mencapai 100\% kumulatif. Pada prinsipnya waktu pengajaran yang diberikan kepada anak-anak dan remaja sudah sangat baik untuk memenuhi kebutuhan dasar kehidupan kerohanian mereka.

\section{Persekutuan}

Mean (rata-rata) persekutuan yang dihadiri anak-anak dan remaja adalah 32,138 minggu dengan standard error of mean 2,137 minggu, maka rata-rata populasi persekutuan pada tingkat kepercayaan 95\% menjadi: 32,138 $\pm(2 \times 2,137$ minggu $)=$ 27,864 sampai 36,412 minggu. Dengan rata-rata kehadiran persekutuan sampel (anakanak dan remaja) 32,138 minggu, diperkirakan rata-rata kehadiran persekutuan populasi (semua jemaat yang ada di departemen Anak dan Remaja adalah antara 27,864 sampai 36,412 minggu.

Angka median 38 minggu menunjukkan bahwa 50\% anak-anak dan remaja menghadiri persekutuan 38 minggu ke atas, dan 50\% menghadiri persekutuan 38 minggu ke bawah.

Standar deviasi adalah 11,507 minggu dan varians adalah 132,409 minggu menunjukkan data semakin bervariasi.

Ukuran skewness adalah $-0,728$, diubah ke angka rasio menjadi: $-0,728 / 0,434=$ -1,677. Karena $-1,677$ terletak pada daerah antara -2 dan +2 , maka bisa dikatakan distribusi sampel data persekutuan adalah normal.

Ukuran kurtosis adalah -1,047, diubah ke angka rasio menjadi: -1,047/0,845 = 1,239. Karena $-1,239$ terletak pada daerah antara -2 dan +2 , maka bisa dikatakan distribusi sampel data persekutuan adalah normal.

Data kehadiran minimum persekutuan anak-anak dan remaja adalah 12 minggu, sedangkan data kehadiran maksimum persekutuan adalah 44 minggu.

Range adalah 32 minggu. Data bervariasi, karena nilai range-nya cukup besar.

Percentiles atau angka persentil: 10\% responden menghadiri persekutuan di bawah 12 minggu, atau rata-rata kehadiran persekutuan 90\% responden di atas 12 minggu. $25 \%$ responden menghadiri persekutuan di bawah 23 minggu. Rata-rata kehadiran persekutuan $50 \%$ responden di bawah 38 minggu, atau rata-rata kehadiran persekutuan 50\% responden di atas 38 minggu. $75 \%$ responden menghadiri persekutuan 
di bawah 42 minggu. Rata-rata kehadiran persekutuan $90 \%$ responden adalah di bawah 43 minggu.

Pada tabel frekuensi tentang tingkat kehadiran persekutuan anak-anak dan remaja, dapat dijelaskan sebagai berikut: Pada baris pertama, responden yang menghadiri persekutuan 12 minggu sebanyak 3 orang atau (3/29 x 100\%) 10,3\% dari 29 sampel yang ada. Berikutnya baris kedua, responden yang menghadiri kelas persekutuan 14 minggu sebanyak 1 orang (1/29 x 100\%) atau hanya 3,4\% dari total sampel. Dengan demikian, kedua frekuensi tersebut mempunyai kumulatif persen sebesar $10,3 \%+3,4 \%$ atau $13,8 \%$. Demikian seterusnya hingga sampai mencapai $100 \%$ kumulatif.

Pada prinsipnya waktu persekutuan rata-rata yang diberikan gereja ini kepada anak-anak dan remaja sudah sangat baik.

\section{Pertumbuhan Rohani}

Mean pertumbuhan rohani anak-anak dan remaja adalah 117,414 dengan standard error of mean 9,809, maka rata-rata populasi pertumbuhan rohani pada tingkat kepercayaan $95 \%$ menjadi $=117,414 \pm(2 \times 9,809)=97,796$ sampai 137,032. Dengan rata-rata skor pertumbuhan rohani sampel (anak-anak dan remaja) 117,414, diperkirakan rata-rata skor pertumbuhan rohani populasi (semua jemaat yang ada di Departemen Anak dan Departemen Remaja adalah antara 97,796 sampai 137,032. Tingkat kepercayaan 95\% menunjukkan bahwa ada kemungkinan kesalahan sebesar 5\% dalam generalisasi data di atas.

Median pada skor 120 menunjukkan bahwa 50\% anak-anak dan remaja memiliki skor pertumbuhan rohani 120 ke atas, dan 50\% memiliki skor 120 ke bawah.

Standar deviasi adalah 52,824 dan varians adalah 2790,394 menunjukkan data semakin bervariasi.

Ukuran skewness adalah $-0,065$, diubah ke angka rasio menjadi: $-0,065 / 0,434=$ $-0,150$. Karena $-0,150$ terletak pada daerah antara -2 dan +2 , maka dikatakan distribusi sampel data pertumbuhan rohani anak-anak dan remaja adalah normal.

Ukuran kurtosis adalah -1,557, diubah ke angka rasio menjadi: -1,557/0,845 = 1,843. Karena $-1,843$ terletak pada daerah antara -2 dan +2 , maka bisa dikatakan distribusi sampel data pertumbuhan rohani anak-anak dan remaja adalah normal. 
Skor pertumbuhan rohani anak-anak dan remaja minimum adalah 45, sedangkan skor maksimum adalah 185. Range dengan skor 140 adalah bervariasi, karena nilainya cukup besar.

Percentiles atau angka persentil: 10\% responden memiliki skor pertumbuhan rohani di bawah 45 , atau rata-rata skor pertumbuhan rohani $90 \%$ responden $(100 \%$ $10 \%$ ) di atas skor 45. 25\% responden memiliki skor pertumbuhan rohani di bawah 60 . Rata-rata skor pertumbuhan rohani 50\% responden di bawah 120, atau rata-rata skor pertumbuhan rohani $50 \%$ responden di atas $120.75 \%$ responden memiliki skor pertumbuhan rohani di bawah 175. Rata-rata skor pertumbuhan rohani $90 \%$ responden adalah di bawah 185 .

Pada tabel frekuensi tingkat pertumbuhan rohani anak-anak dan remaja, dapat dijelaskan sebagai berikut: Pada baris pertama, responden yang memiliki skor pertumbuhan rohani 45 sebanyak 3 orang atau 10,3\%. Berikutnya baris kedua, responden yang memiliki skor pertumbuhan rohani 50 sebanyak 2 orang atau hanya 6,9\%. Dengan demikian, kedua frekuensi tersebut mempunyai kumulatif persen sebesar $10,3 \%+6,9 \%$ atau $17,2 \%$. Demikian seterusnya hingga sampai mencapai $100 \%$ kumulatif.

Pada prinsipnya, dapat dikatakan bahwa tingkat pertumbuhan rohani anak-anak dan remaja mengalami peningkatan yang sangat baik bila mereka rajin, setia dan dengan sungguh hati menghadiri kelas pengajaran dan persekutuan.

\section{Hasil Analisa Uji Hipotesa}

\section{Hasil Analisa Uji Hipotesa I}

Untuk mengetahui keeratan hubungan dan seberapa besar pengaruh pengajaran terhadap pertumbuhan rohani anak-anak dan remaja, ditunjukkan berdasarkan hasil analisa koefisien korelasi dan R Square.

Besar hubungan antar variabel pengajaran dengan pertumbuhan rohani yang hitung dengan koefisien korelasi adalah 0,952. Hal ini menunjukkan hubungan yang sangat erat antara tingkat kehadiran di kelas pengajaran dengan tingkat pertumbuhan rohani anak-anak dan remaja. Arah hubungan yang positif menunjukkan semakin tinggi tingkat kehadiran anak-anak dan remaja di kelas pengajaran akan membuat pertumbuhan rohani mereka cenderung meningkat. Demikian pula sebaliknya, makin rendah tingkat kehadiran anak-anak dan remaja di kelas pengajaran makin rendah pula tingkat pertumbuhan rohani mereka. 
Tingkat signifikansi koefisien korelasi yang diukur berdasarkan probabilitas menghasilkan angka 0,000 atau praktis 0 . Karena probabilitas jauh di bawah 0,025 (nilai probabilitas 0,025 adalah hasil dari 0,05/2; hal ini disebabkan uji dilakukan dua sisi), maka korelasi antara pengajaran dengan pertumbuhan rohani anak-anak dan remaja sangat erat dan sangat nyata sekali. Artinya ada pengaruh positif antara kehadiran di pengajaran terhadap pertumbuhan rohani anak-anak dan remaja. Hal ini diperkuat berdasarkan tanda ** (flag significant correlations) yang diberikan SPSS (Santoso, 2009 : 309-310) pada pasangan data variabel X1 (pengajaran) dan Y (pertumbuhan rohani) yang dikorelasikan.

R Square (koefisien determinasi) sebesar 0,907 atau 91\%, artinya menunjukkan bahwa perubahan pengajaran sedikit saja 91\% dapat menjelaskan perubahan (naik turunnya) pertumbuhan rohani anak-anak dan remaja.

Untuk mengetahui pengaruh pengajaran terhadap pertumbuhan rohani anak-anak dan remaja dan apakah variabel pengajaran ini dapat dipakai sebagai prediktor terhadap pertumbuhan rohani, dapat dijelaskan sebagai berikut:

Standard error of estimate adalah 16,402, jauh lebih kecil dari standar deviasi pertumbuhan rohani (satuan yang dipakai adalah variabel dependen), yaitu sebesar 52,824 , maka model regresi lebih bagus dalam bertindak sebagai prediktor pertumbuhan rohani daripada rata-rata pertumbuhan rohani itu sendiri.

Dari uji Anova atau F test, didapat F hitung adalah 263,431 dengan tingkat signifikansi 0,000 . Karena probabilitas $(0,000)$ jauh lebih kecil dari 0,05, maka model regresi ini bisa dipakai untuk memprediksi pertumbuhan rohani anak-anak dan remaja.

Persamaan regresinya adalah: $\mathrm{Y}=\mathrm{a}+\mathrm{b} 1 \mathrm{X} 1 \rightarrow \mathrm{Y}=-24,195+4,748 \mathrm{X} 1$, di mana $\mathrm{Y}=$ pertumbuhan rohani dan $\mathrm{X} 1$ = pengajaran. Hasil analisa menjelaskan:

Konstanta sebesar -24,195 menyatakan bahwa jika anak-anak dan remaja tidak menghadiri kelas pengajaran, maka skor pertumbuhan rohani mereka adalah sebesar 24,195 .

Koefisien regresi sebesar 4,748 menyatakan bahwa setiap peningkatan 1 minggu kehadiran di kelas pengajaran akan meningkatkan skor pertumbuhan rohani sebesar 4,748. Namun sebaliknya, jika tingkat kehadiran di kelas pengajaran turun 1 minggu, maka skor pertumbuhan rohani juga diprediksi mengalami penurunan sebesar 4,748. 
Uji t adalah untuk menguji signifikansi konstanta dan variabel independen (pengajaran) dengan membandingkan statistik t hitung dengan statistik t tabel, Santoso (2009 : 331) memberikan pedoman prosedur mencari statistik tabel, dengan kriteria:

Tingkat signifikansi $(\alpha)=10 \%$ untuk uji dua sisi. df (derajat kebebasan) $=$ jumlah data - 2. Uji dilakukan dua sisi, karena ingin mengetahui signifikan tidaknya koefisien regresi, dan bukan mencari 'lebih kecil' atau 'lebih besar'.

Hipotesis I: Semakin tinggi tingkat pengajaran, maka semakin tinggi tingkat pertumbuhan rohani anak-anak dan remaja.

$$
\begin{aligned}
& \text { Ho : } \beta=0 \\
& \text { Ha } 1: \beta>0
\end{aligned}
$$

Hasil perhitungan menunjukkan: Dengan membandingkan statistik $\mathrm{t}$ hitung dengan statistik $\mathrm{t}$ tabel; $\mathrm{t}$ hitung $=16,231$ dan $\mathrm{t}$ tabel $(0,05 ; 27)=1,703$. Jadi, $\mathrm{t}$ hitung $>$ t tabel.

Karena statistik t hitung lebih besar dari statistik t tabel, maka Ho ditolak dan $\mathrm{Ha}$ 1 diterima. Artinya, ada pengaruh tinggi rendahnya tingkat pengajaran terhadap tinggi rendahnya tingkat pertumbuhan rohani anak-anak dan remaja.

Berdasarkan probabilitas, Santoso (2009 : 331) mengatakan: Jika probabilitas > 0,025, maka Ho diterima. Jika probabilitas < 0,025, maka Ho ditolak. Karena signifikansi/probabilitas adalah 0,000 jauh di bawah 0,025, maka Ho ditolak dan Ha 1 diterima, atau koefisien regresi signifikan. Artinya, tingkat kehadiran di kelas pengajaran benar-benar berpengaruh secara signifikan terhadap tingkat pertumbuhan rohani anak-anak dan remaja.

\section{Hasil Analisa Uji Hipotesis II}

Untuk mengetahui keeratan hubungan dan seberapa besar pengaruh persekutuan terhadap pertumbuhan rohani anak-anak dan remaja, ditunjukkan berdasarkan hasil analisa koefisien korelasi dan R Square.

Besar hubungan antar variabel persekutuan dengan pertumbuhan rohani yang hitung dengan koefisien korelasi adalah 0,879. Hal ini menunjukkan hubungan yang sangat erat antara tingkat kehadiran di persekutuan dengan tingkat pertumbuhan rohani anak-anak dan remaja. Arah hubungan yang positif menunjukkan semakin tinggi tingkat kehadiran anak-anak dan remaja di persekutuan akan membuat pertumbuhan rohani mereka cenderung meningkat juga. Demikian pula sebaliknya, makin rendah tingkat 
kehadiran anak-anak dan remaja di persekutuan makin rendah pula tingkat pertumbuhan rohani mereka.

Tingkat signifikansi koefisien korelasi yang diukur berdasarkan probabilitas menghasilkan angka 0,000 atau praktis 0 jauh di bawah 0,025, maka korelasi antara persekutuan dengan pertumbuhan rohani anak-anak dan remaja sangat erat dan sangat nyata sekali. Artinya, ada pengaruh positif antara kehadiran di persekutuan terhadap pertumbuhan rohani anak-anak dan remaja. Hal ini diperkuat berdasarkan tanda ** (flag significant correlations) pada pasangan data variabel $\mathrm{X} 2$ (persekutuan) dan $\mathrm{Y}$ (pertumbuhan rohani) yang dikorelasikan.

R Square (koefisien determinasi) sebesar 0,773 atau 77\%, artinya menunjukkan bahwa perubahan persekutuan sedikit saja $77 \%$ dapat menjelaskan perubahan (naik turunnya) pertumbuhan rohani anak-anak dan remaja.

Untuk mengetahui apakah variabel persekutuan ini dapat dipakai sebagai prediktor terhadap pertumbuhan rohani, dapat dijelaskan sebagai berikut:

Standard error of estimate adalah 25,620, jauh lebih kecil dari standar deviasi pertumbuhan rohani, yaitu sebesar 52,824, maka model regresi lebih bagus dalam bertindak sebagai prediktor pertumbuhan rohani daripada rata-rata pertumbuhan rohani itu sendiri. Dari uji Anova atau F test, didapat F hitung adalah 92,032 dengan tingkat signifikansi 0,000. Karena probabilitas $(0,000)$ jauh lebih kecil dari 0,05, maka model regresi ini bisa dipakai untuk memprediksi pertumbuhan rohani anak-anak dan remaja. Persamaan regresinya adalah: $\mathrm{Y}=\mathrm{a}+\mathrm{b} 2 \mathrm{X} 2 \rightarrow \mathrm{Y}=-12,313+4,037 \mathrm{X} 2$, di mana $\mathrm{Y}=$ pertumbuhan rohani dan $\mathrm{X} 2=$ persekutuan.

Hasil analisis menjelaskan:

Konstanta sebesar -12,313 menyatakan bahwa jika anak-anak dan remaja tidak menghadiri pertemuan persekutuan, maka skor pertumbuhan rohani mereka adalah sebesar $-5,879$.

Koefisien regresi sebesar 4,037 menyatakan bahwa setiap peningkatan 1 minggu kehadiran di pertemuan persekutuan akan meningkatkan skor pertumbuhan rohani sebesar 4,037. Namun sebaliknya, jika tingkat kehadiran di pertemuan persekutuan turun 1 minggu, maka skor pertumbuhan rohani juga diprediksi mengalami penurunan sebesar 4,037. Uji t untuk menguji signifikansi konstanta dan variabel independen (persekutuan). 
Hipotesis II: Semakin tinggi tingkat persekutuan, maka semakin tinggi tingkat pertumbuhan rohani anak-anak dan remaja.

Ho : $\beta=0$

Ha $2: \beta>0$

Hasil perhitungan menunjukkan:

Dengan membandingkan statistik $\mathrm{t}$ hitung dengan statistik $\mathrm{t}$ tabel: $\mathrm{t}$ hitung $=$ 9,593 dan $\mathrm{t}$ tabel $(0,05 ; 27)=1,703$. Jadi, $\mathrm{t}$ hitung $>\mathrm{t}$ tabel. Karena statistik $\mathrm{t}$ hitung lebih besar dari statistik t tabel, maka Ho ditolak dan Ha 2 diterima. Artinya, ada pengaruh tinggi rendahnya tingkat persekutuan terhadap tinggi rendahnya tingkat pertumbuhan rohani anak-anak dan remaja.

Berdasarkan probabilitas: Karena signifikansi/probabilitas adalah 0,000 jauh di bawah 0,025, maka Ho ditolak dan Ha 2 diterima, atau koefisien regresi signifikan. Artinya, tingkat kehadiran di pertemuan persekutuan benar-benar berpengaruh secara signifikan terhadap tingkat pertumbuhan rohani anak-anak dan remaja.

\section{Hasil Analisa Uji Hipotesis III}

Untuk mengetahui keeratan hubungan dan seberapa besar pengaruh pengajaran dan persekutuan secara bersamaan terhadap pertumbuhan rohani anak-anak dan remaja, ditunjukkan berdasarkan hasil analisa koefisien korelasi berganda dan R Square.

Besar hubungan antar variabel pengajaran dan persekutuan secara bersamaan dengan pertumbuhan rohani yang hitung dengan koefisien korelasi adalah 0,953. Hal ini menunjukkan hubungan yang sangat erat antara tingkat kehadiran di kelas pengajaran dan persekutuan secara bersamaan dengan tingkat pertumbuhan rohani anak-anak dan remaja. Arah hubungan yang positif menunjukkan semakin tinggi tingkat kehadiran anak-anak dan remaja di pengajaran dan persekutuan secara bersamaan akan membuat pertumbuhan rohani mereka cenderung meningkat juga. Demikian pula sebaliknya, makin rendah tingkat kehadiran anak-anak dan remaja di pengajaran dan persekutuan secara serempak akan makin rendah pula tingkat pertumbuhan rohani mereka.

Terjadi korelasi yang sangat kuat antara variabel pengajaran dengan persekutuan, yaitu 0,953 . Hal ini menandakan adanya multikolinieritas, atau korelasi di antara variabel bebas.

Tingkat signifikansi koefisien korelasi dua sisi dari output (diukur dari probabilitas) menghasilkan angka 0,000 atau praktis 0 jauh di bawah 0,025 , maka korelasi di antara pengajaran dan persekutuan secara bersamaan dengan pertumbuhan 
rohani anak-anak dan remaja sangat erat dan sangat nyata sekali. Artinya, ada pengaruh positif antara kehadiran di pengajaran dan persekutuan secara bersamaan terhadap pertumbuhan rohani anak-anak dan remaja. Hal ini diperkuat berdasarkan tanda ** (flag significant correlations) pada pasangan data variabel $\mathrm{X} 1$ (pengajaran) dan $\mathrm{X} 2$ (persekutuan) terhadap Y (pertumbuhan rohani) yang dikorelasikan.

Tabel variables entered menunjukkan bahwa tidak ada variabel yang dikeluarkan, atau dengan kata lain kedua variabel bebas dimasukkan dalam perhitungan regresi.

R Square (koefisien determinasi) sebesar 0,908 atau 91\%, artinya 91\% dari variasi skor pertumbuhan rohani anak-anak dan remaja bisa dijelaskan oleh variabel pengajaran dan persekutuan yang dihadiri anak-anak dan remaja.

Untuk mengetahui pengaruh pengajaran dan persekutuan secara bersamaan terhadap pertumbuhan rohani anak-anak dan remaja dan apakah kedua variabel ini secara bersamaan dapat dipakai sebagai prediktor terhadap pertumbuhan rohani, dapat dijelaskan sebagai berikut:

Standard error of estimate adalah 16,607, jauh lebih kecil dari standar deviasi pertumbuhan rohani, yaitu sebesar 52,824, maka model regresi sangat bagus dalam bertindak sebagai prediktor pertumbuhan rohani daripada rata-rata pertumbuhan rohani itu sendiri. Dari uji Anova atau F test, didapat F hitung adalah 128,647 dengan tingkat signifikansi 0,000 . Karena probabilitas $(0,000)$ jauh lebih kecil dari 0,05, maka model regresi ini bisa dipakai untuk memprediksi pertumbuhan rohani anak-anak dan remaja. Atau bisa dikatakan pengajaran dan persekutuan secara bersama-sama sangat berpengaruh terhadap pertumbuhan rohani anak-anak dan remaja.

Persamaan regresinya adalah: $\mathrm{Y}=\mathrm{a}+\mathrm{b} 1 \mathrm{X} 1+\mathrm{b} 2 \mathrm{X} 2 \rightarrow \mathrm{Y}=-23,377+5,204 \mathrm{X} 1$ $+(-0,449 \mathrm{X} 2)$, di mana $\mathrm{Y}=$ pertumbuhan rohani, $\mathrm{X} 1=$ pengajaran, dan $\mathrm{X} 2=$ persekutuan. Hasil analisis menjelaskan:

Konstanta sebesar -23,377 menyatakan bahwa jika tidak ada pengajaran dan persekutuan yang dihadiri anak-anak dan remaja, maka skor pertumbuhan rohani mereka adalah sebesar -23,377. Koefisien regresi X1 sebesar 5,204 menyatakan bahwa setiap peningkatan 1 minggu kehadiran pengajaran akan meningkatkan skor pertumbuhan rohani sebesar 5,204. Koefisien regresi X2 sebesar -0,449 menyatakan bahwa setiap peningkatan 1 minggu kehadiran di pertemuan persekutuan akan meningkatkan skor pertumbuhan rohani sebesar $-0,449$. 
Uji t untuk menguji signifikansi konstanta dan variabel independen (pengajaran dan persekutuan). Hipotesa III: Semakin tinggi tingkat pengajaran dan persekutuan, maka semakin tinggi tingkat pertumbuhan rohani anak-anak dan remaja.

Ho : $\beta=0$

Ha $3: \beta>0$

Hasil perhitungan menunjukkan:

Dengan membandingkan statistik $\mathrm{t}$ hitung dengan statistik $\mathrm{t}$ tabel: $\mathrm{t}$ hitung $=$ 6,185 dan $-0,580$, sehingga $t$ hitung menjadi $6,185-0,580=5,605 ; \mathrm{t}$ tabel $(0,05 ; 26)=$ 1,706. Jadi, $\mathrm{t}$ hitung $>\mathrm{t}$ tabel. Karena statistik $\mathrm{t}$ hitung lebih besar dari statistik $\mathrm{t}$ tabel, maka Ho ditolak dan Ha 3 diterima, atau koefisien regresi signifikan. Artinya, ada pengaruh tinggi rendahnya tingkat pengajaran dan persekutuan secara bersamaan terhadap tinggi rendahnya tingkat pertumbuhan rohani anak-anak dan remaja.

Berdasarkan probabilitas:

Karena signifikansi/probabilitas adalah 0,000 jauh di bawah 0,025, maka Ho ditolak dan Ha 3 diterima, atau koefisien regresi signifikan. Artinya, pengajaran dan persekutuan secara bersamaan benar-benar berpengaruh secara signifikan terhadap tingkat pertumbuhan rohani anak-anak dan remaja.

\section{Bahasan Analisis}

\section{Pengaruh Pengajaran Terhadap Pertumbuhan Rohani}

Hipotesis I, bahwa semakin tinggi tingkat pengajaran, maka semakin tinggi tingkat pertumbuhan rohani anak-anak dan remaja dapat dibuktikan. Hal ini diperkuat dari hasil analisa uji hipotesa yang telah dilakukan dengan menggunakan analisa korelasi dan regresi. Dengan derajat kepercayaan sebesar 95\% menunjukkan bahwa memang benar ada pengaruh tingginya tingkat pengajaran anak-anak dan remaja terhadap tingkat pertumbuhan rohani mereka.

R Square sebesar 91\% dapat menjelaskan bahwa sedikit saja perubahan di kelas pengajaran, 91\% dapat menjelaskan perubahan (naik turunnya) tingkat pertumbuhan rohani anak-anak dan remaja. Artinya, sedikit saja terjadi peningkatan dalam pengajaran akan sangat berpengaruh terhadap kenaikan tingkat pertumbuhan rohani. Demikian sebaliknya, sedikit saja terjadi penurunan dalam pengajaran akan sangat berpengaruh terhadap turunnya pertumbuhan rohani mereka. 


\section{Pengaruh Persekutuan terhadap Pertumbuhan Rohani}

Hipotesis II, bahwa semakin tinggi tingkat persekutuan, maka semakin tinggi tingkat pertumbuhan rohani anak-anak dan remaja dapat dibuktikan. Hal ini didukung dengan hasil analisa uji hipotesa yang telah dilakukan dengan menggunakan analisa korelasi dan regresi. Derajat kepercayaan sebesar 95\% menunjukkan bahwa ada pengaruh tingginya persekutuan yang anak-anak dan remaja hadiri terhadap pertumbuhan rohani mereka.

R Square sebesar $77 \%$ dapat menjelaskan bahwa sedikit saja perubahan di persekutuan, $77 \%$ dapat menjelaskan perubahan (naik turunnya) pertumbuhan rohani anak-anak dan remaja. Artinya, bila persekutuan naik akan berpengaruh terhadap kenaikan tingkat pertumbuhan rohani. Demikian sebaliknya, sedikit saja terjadi penurunan dalam persekutuan akan sangat berpengaruh terhadap turunnya pertumbuhan rohani mereka.

\section{Pengaruh Pengajaran dan Persekutuan terhadap Pertumbuhan Rohani}

Hipotesis III, bahwa semakin tinggi tingkat pengajaran dan persekutuan, maka semakin tinggi tingkat pertumbuhan rohani anak-anak dan remaja dapat dibuktikan. Hal ini diperkuat dari hasil analisa uji hipotesa yang telah dilakukan dengan menggunakan analisa korelasi dan regresi. Dengan derajat kepercayaan sebesar 95\% menunjukkan bahwa memang benar ada pengaruh tingginya tingkat kehadiran anak-anak dan remaja di pengajaran dan persekutuan terhadap pertumbuhan rohani mereka.

Dengan R Square sebesar 91\%, ini dapat menjelaskan bahwa sedikit saja perubahan di kelas pengajaran dan pertemuan persekutuan, 91\% dapat menjelaskan perubahan (naik turunnya) tingkat pertumbuhan rohani anak-anak dan remaja. Artinya, sedikit saja terjadi peningkatan dalam pengajaran dan persekutuan akan sangat berpengaruh terhadap kenaikan tingkat pertumbuhan rohani anak-anak dan remaja. Demikian sebaliknya, sedikit saja terjadi penurunan dalam pengajaran dan persekutuan akan sangat berpengaruh terhadap turunnya pertumbuhan rohani mereka.

Dengan meningkatkan kehadiran di kelas pengajaran dan pertemuan persekutuan lebih tinggi, maka anak-anak dan remaja akan menerima makanan rohani yang cukup bagi kebutuhan rohani mereka untuk terus bertumbuh mencapai kedewasaan rohani dan tingkat pertumbuhan yang sesuai dengan kepenuhan Kristus. 


\section{Kesimpulan}

Berdasarkan hasil analisa dan bahasan analisa, maka dapatlah ditarik kesimpulan sebagai berikut:

Pertama, semakin tinggi tingkat pengajaran firman Tuhan yang dihadiri anakanak dan remaja, maka semakin tinggi tingkat pertumbuhan rohani mereka. Dengan derajat kepercayaan sebesar 95\% menunjukkan bahwa ada pengaruh antara tingkat pengajaran terhadap peningkatan pertumbuhan rohani anak-anak dan remaja. R Square sebesar 91\% menunjukkan bahwa perubahan pengajaran sedikit saja, 91\% dapat menjelaskan perubahan (naik turunnya) pertumbuhan kerohanian anak-anak dan remaja.

Kedua, semakin tinggi tingkat persekutuan yang dihadiri anak-anak dan remaja, maka semakin tinggi tingkat pertumbuhan rohani mereka. Dengan derajat kepercayaan sebesar 95\% menunjukkan bahwa ada pengaruh antara peningkatan persekutuan terhadap peningkatan pertumbuhan rohani anak-anak dan remaja. R Square $77 \%$ menunjukkan bahwa perubahan persekutuan sedikit saja, $77 \%$ dapat menjelaskan perubahan (naik turunnya) pertumbuhan rohani anak-anak dan remaja.

Ketiga, semakin tinggi tingkat pengajaran firman Tuhan dan persekutuan yang dihadiri anak-anak dan remaja secara bersamaan, maka semakin tinggi tingkat pertumbuhan rohani mereka. Dengan derajat kepercayaan 95\% menunjukkan bahwa ada pengaruh antara peningkatan kehadiran dalam kelas pengajaran dan persekutuan secara bersamaan terhadap peningkatan pertumbuhan rohani anak-anak dan remaja. R Square sebesar $91 \%$ menunjukkan bahwa perubahan tingkat pengajaran dan persekutuan secara bersamaan sedikit saja, 91\% dapat menjelaskan perubahan (naik turunnya) pertumbuhan rohani anak-anak dan remaja.

\section{Rekomendasi}

Penulis melihat beberapa keterbatasan dapat mempengaruhi hasil penelitian ini, karena itu penulis menyarankan perlu dilakukan penelitian lebih lanjut untuk mengetahui signifikansi keterkaitan antara pengajaran dan persekutuan terhadap pertumbuhan kerohanian anak-anak dan remaja dalam ruang lingkup yang lebih besar. 


\section{Referensi}

Alkitab Perjanjian Lama \& Perjanjian Baru. Jakarta: Lembaga Alkitab Indonesia, 2004. Boehlke, Robert R. Sejarah Perkembangan Pikiran dan Praktek PAK. Jakarta: BPK Gunung Mulia, 2000.

Cho, Paul Yonggi Bukan Sekedar Jumlah. Jakarta: Yayasan Pekabaran Injil Samuel, 1985.

Comiskey, Joel. Ledakan Kelompok Sel. Jakarta: Metanoia, 1998.

Dayan, Anto. Pengantar Metode Statistik. Jakarta, 1983.

Endra, Himawan D. Dewasa Dalam Kristus. Jakarta: CV Bina Media Informasi, 2003.

Homrighausen, EG dan Enklaar, IH. Pendidikan Agama Kristen. Jakarta: BPK Gunung Mulia, 1982.

Jenson, Ron \& Stevens, Jim. Dinamika Pertumbuhan Gereja. Malang: Gandum Mas, 2004.

Lenga, Daniel. Pertumbuhan Gereja. Jakarta: Diktat, 2003.

Santoso, Singgih. Panduan Lengkap. Jakarta: PT Elex Media Komputindo, 2009.

Tanto, Obaja S. Kelompok Sel. Solo: Departemen Media GBI Keluarga Allah, 2000.

Tanto, Obaja S. Kelompok Sel Jilid II . Solo: Departemen Media GBI Keluarga Allah, 2000.

Wagner, C. Peter. Gempa Gereja. Jakarta: Nafiri Gabriel, 2000.

Wagner, C. Peter. Gereja-gereja Rasuli Yang Baru. Jakarta: Yayasan Pekabaran Injil "Immanuel", 2001.

Warren, Rick. Pertumbuhan Gereja Masa Kini. Malang: Gandum Mas, 2004. 